\title{
Much ado about \$100 million
}

$\mathrm{I}$ $\mathrm{t}$ almost seems as if the revenues generated by hospital parking fees are rivalled only by myriad nuances of opinion that Canadians, with the exception of most hospital administrators, have about the merits of said fees.

A cynical observer might even suggest that the ferocity with which proponents of hospital parking fees responded to a $C M A J$ editorial calling for an end to parking-centred health care (www.cmaj.ca/lookup/doi/10.1503 /cmaj.111846) is particularly puzzling in light of the findings of an informal survey which indicates that Canada's major hospitals generate only about $\$ 100$ million per year in parking fees.

That is, of course, not an insubstantial sum. Nor is it entirely profit as several hospitals report their gross revenues and say that their net is far less. But assuming that it was $\$ 100$ million per year, that's just $0.17 \%$ of the $\$ 58.4$ billion that the Canada Institute for Health Information estimates was spent on hospitals in 2011, and just $0.05 \%$ of the $\$ 200$ billion that Canadians were projected to spend on health care (http://secure.cihi.ca/cihiweb/products /nhex_trends_report_2011_en.pdf).

Yet, while Canadians appeared to all but lineup at media microphones to argue that they find parking fees a hardship, proponents of hospital parking fees argue that every penny matters and they need the revenues for programs and services, equipment and other costs which aren't covered by provincial allotments for annual operating fees.

For example, the 274-bed, acute care Queen Elizabeth Hospital in Charlottetown, Prince Edward Island, wouldn't meet its budget targets without parking revenues, says Denise Lewis Fleming, executive director of financial services for Health PEI.

The hospital will not stop charging parking fees until another source of income is found to replace the revenues that accrue from charging people, she stresses.

Nor does Alberta Health Services

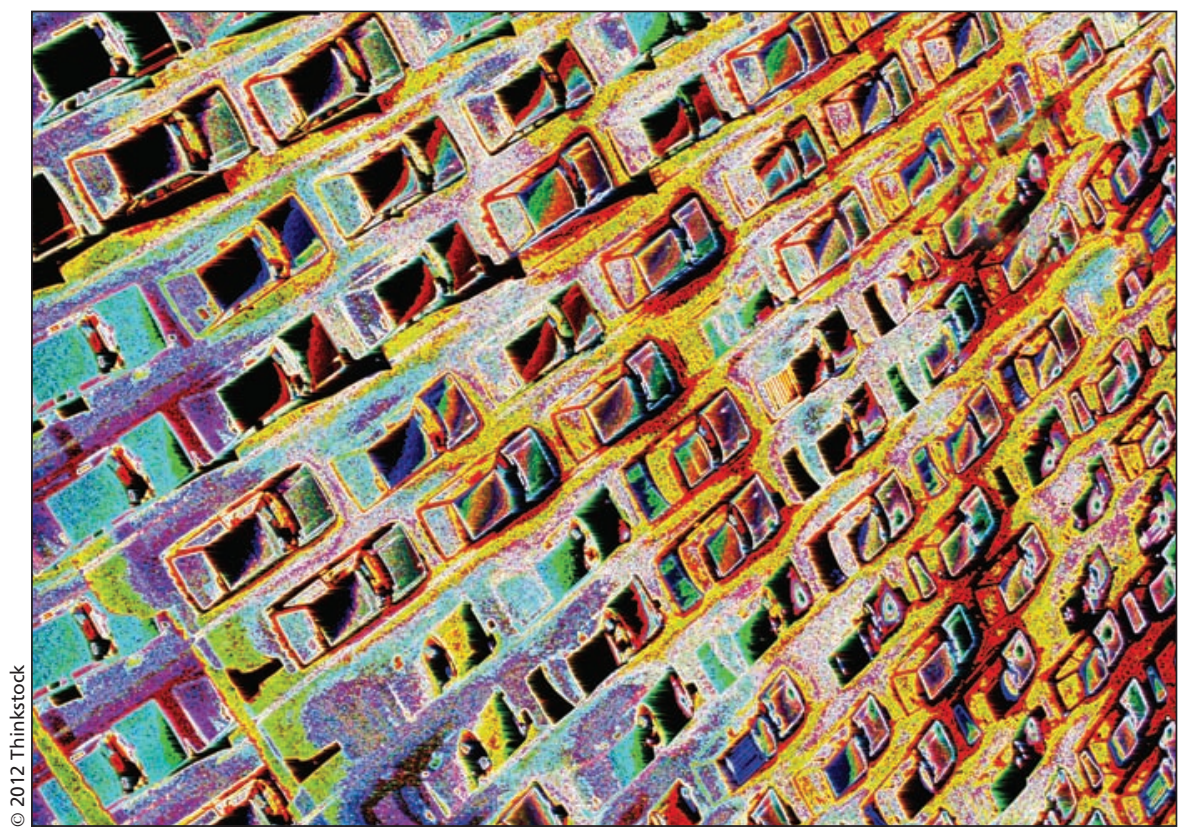

Parking fees at hospitals generate impassioned opinion. While Canadians appeared to all but line up at media microphones to argue that they find fees a hardship, proponents argue that every penny matters and they need the revenues for programs and services, equipment and other costs which aren't covered by provincial allotments for annual operating fees.

have any plans to discontinue charging parking fees, although it lost \$5 million on parking in 2011, earning \$55 million in revenues but needing $\$ 60$ million for parking lot operations and maintenance, spokesperson Bruce Conway writes in an email.

Moreover, Alberta Health Services has had to spend \$200 million over the past year to open four new parkades one in Lethbridge, one in Edmonton and two in Calgary, Conway writes. "If there were no parking revenues, there'd be far less parking structures and therefore far less parking available."

Several hospital administrators also indicated that their facilities have found mechanisms to support Canadians for whom parking fees have proven to be an excessive burden. Some say they issue monthly parking passes for frequent visitors or long-term patients, while others say they offer discounts or note that patients always have the option to challenge parking tickets, as was the case in a highly publicized situation in St. John's,
Newfoundland and Labrador, in which a cancer outpatient who refused to interrupt his chemotherapy to feed an expired meter, took the matter to court and had the case against him dismissed.

The St. John's Health Science Centre is hoping to avoid such problems in the future by installing a pay-as-you-go parking system, rather than meters, in September 2012, Zelda Burt, spokeswoman for the hospital, writes in an email.

Hospital administrators also dismissed suggestions that there's an inherent unfairness in either charging parking fees, or charging higher parking fees, for patients seeking treatment in urban hospitals.

That's just part of the reality of life, administrators argue, as fees are essentially determined by market value.

For example, the Vancouver General Hospital in British Columbia has the highest parking rate $-\$ 7.50$ per hour to a maximum $\$ 20$ per day — of all similar facilities in the lower mainland simply because the interior of the 
city has the most competitive market for parking, says spokesperson Roy Thorpe-Dorward.

Charging market rates ensures that available spots aren't gobbled up by people other than patients or visitors, the officials argue. "Where facilities are located in areas that have other paid parking, having no charge would likely result in lots being filled with nonpatients who had other reasons to be in the area," Kathryn McBurney, spokesperson for the Winnipeg Regional Health Authority, writes in an email.

Parking economists concur.

Paid parking lots also tend to operate more efficiently, Jos van Ommeren, professor of economic sciences, business administration and econometrics at Vrije Universiteit Amsterdam in the Netherlands, writes in an email. Free parking at hospitals would result in abuse, he argues, though he adds that it is important that hospitals not reap excessive revenues at the expense of patients.

"I think what is important that the hospital does not charge more than the actual cost of parking. For hospitals in urban areas, the cost of parking may be relatively high," van Ommeren writes. "Usually, it is a bad idea to make a good, including parking, for free. Asking a positive price makes people choose alternatives."

Clearly, most hospitals are in fact charging more than the actual cost of maintaining parking operations or there wouldn't be any profits to pour into hospital services, equipment or whatever other purpose for which a hospital might decide to expend revenues.

According to CMAJ's informal survey, those revenues, charges and uses, by facility, include:

- Eastern Health, St. John's Newfoundland and Labrador

Fee: Metered parking, 25 cents for 20 minutes.

Revenues: A gross $\$ 905$ 075, projected for fiscal 2010/11, according to spokesperson Zelda Burt.

Use: "General operational expenses," Burt writes in an email.

- Capital Health, Halifax, Nova Scotia

Fee: Vary by facility but typically $\$ 1.50$ per half hour to daily maximum of $\$ 13$.
Revenues: A projected net $\$ 4.9$ million in 2011, spokesman Cory Burris writes in an email.

Use: "Patient care equipment that is not funded by the province," Burris writes.

- Queen Elizabeth Hospital, Charlottetown, PEI

Fee: $\$ 1.50$ per hour to a maximum $\$ 7$ per day.

Revenues: A gross $\$ 375000$ per year, spokesperson Denise Lewis Fleming says.

Use: "In 1993, the health authority responsible for the Queen Elizabeth Hospital chose to implement parking fees as one of the ways in order to meet its budget targets," says Lewis Fleming.

- McGill University Health Centre, Montréal, Quebec

Fee: \$17-\$18 per 24-hour period.

Revenues: Data is only available from the Agence de la santé et des services sociaux de Montréal or by filing an access to information request, Ian Popple, manager of media relations, writes in an email.

Use: "It should be noted that this is revenue (not profit); it is important when reporting these figures to consider (and deduct) the significant costs related to staffing, maintenance and snow removal (our parking sites are outdoors). Any money left over goes towards improvements to health care and its delivery. These projects are many and varied, so we cannot be more specific," Popple writes.

- The Ottawa Hospital, Ontario

Fee: $\$ 3.50$ per half hour to a maximum $\$ 13$ per day.

Revenues: $\$ 10.8$ million (www .cmaj.ca/lookup/doi/10.1503/cmaj .111846).

Use: Equipment.

- University Health Network (Princess Margaret, Toronto General and Toronto Western hospitals), Toronto, Ontario

Fee: $\$ 4.50$ per half hour to a maximum $\$ 28$ per day, lower overnight and weekend rates.

Revenues: A net \$7 million in 2011, Public Affairs Assistant Erica Di Maio writes in an email.

Use: "Our level of patient care," Di Maio writes.
- Hospital for Sick Children (SickKids), Toronto, Ontario

Fee: $\$ 5$ per half hour to a maximum $\$ 30$ per day (a maximum $\$ 16$ per day for parents).

Revenues: $\$ 4.5$ million to $\$ 5$ million annually, according to spokesperson Matet Nebres.

Use: "Offset SickKids operating costs," Nebres writes in an email.

- Winnipeg Regional Health Authority (including two tertiary hospitals and four community hospitals), Manitoba

Fee: Vary by facility. For example, St-Boniface Hospital charges \$1.75 per half hour. Daily rates vary by parkade (www.sbgh.mb.ca/visitors /parking.html). "Hospitals set their own rates, depending on demand of the location and based upon similar rates found at other lots in the area," spokesperson Kathryn McBurney writes in an email.

Revenues: Parking revenues are "not specifically separated out and as there are several healthcare sites, to compile specifically the parkades information accurately for your needs it would be best to file a FIPPA [freedom of information request]," McBurney writes.

Use: Revenues are "reinvested in infrastructure and additional ancillary services (parkades operations such as cleaning, heat, light, machines for in and out and tickets, lot staff etc.)," McBurney writes.

- Regina Qu'Appelle Health Region, Saskatchewan

Fee: No comment, says spokesperson Jenna Webb.

Revenues: No comment.

Use: No comment.

- Saskatoon Health Region, Saskatchewan

Fee: $\$ 2$ for first half hour, $\$ 3$ per hour thereafter, to a maximum of $\$ 15$ per day at Royal University Hospital, Saskatoon City Hospital and St. Paul's Hospital

Revenues: $\$ 6.8$ million in fiscal 2010/11 "or $0.7 \%$ of our total regional revenue," spokesperson Linda Walker writes in an email.

Use: "Revenue is used first to fund the operations and maintenance of the parking lots/structures includ- 
ing interest costs for parking specific debt. The remainder of the revenue is part of a general revenue pool that funds regional programs and services. We do not allocate parking revenue to a specific program or service," Walker writes.

\section{- Alberta Health Services}

Fee: Vary provincewide by facility. At Calgary's Foothills Medical Centre, the rate is $\$ 1.75$ per hour to a maximum of $\$ 13$, except for lot 10 , which charges $\$ 2$ per half hour, to a maximum \$16 per day (www.alberta healthservices.ca/HospitalsFacilities /hf-pmap-foothills-medical-centre .pdf).

Revenues: A projected gross of $\$ 55$ million for fiscal 2011/12, which will represent a loss of $\$ 5$ million in 2011, departmental spokesman Bruce Conway writes in an email. "But this was covered by a contingency fund from previous years."

Use: "Net parking revenues are redirected back into the AHS Parking Services to cover the cost of infrastructure repairs, new builds, paving and snow removal, for instance," Conway writes. "Within the last year, AHS financed over $\$ 200$ million to build and open four new parkades in Lethbridge, Cal- gary (South Health Campus and Foothills Medical Centre) and Edmonton (Edmonton Clinic). If there were no parking revenues, there'd be far less parking structures and therefore far less parking available. Free parking would only be a benefit if there was, in fact, parking available."

- Fraser Health Authority (12 acute care hospitals) in lower mainland British Columbia

Fee: Vary by facility. The Vancouver General Hospital, for example, charges $\$ 7.50$ per hour to a maximum \$20 daily, says spokesperson Roy Thorpe-Dorward.

Revenues: A gross \$14 million in 2010, Thorpe-Dorward says.

Use: Parking services and general revenue fund.

- Whitehorse General Hospital, Yukon Territory

Fee: None.

Revenues: None.

Use: Not applicable.

- Stanton Territorial Hospital, Yellowknife, Northwest Territories

Fee: None.

Revenues: None.

Use: Not applicable.

- Qikiqtani General Hospital, Iqaluit, Nunavut
Fee: None.

Revenues: None.

Use: Not applicable.

The survey is by no means comprehensive. Other facilities across the country have reported revenues to other publications. For example, in the Toronto area, the Sunnybrook Hospital earns about \$6 million annually, the North York General Hospital about \$5.5 million, the Scarborough Hospital about \$3.6 million, Mount Sinai Hospital about $\$ 1$ million to $\$ 1.5$ million and St. Michael's Hospital \$122 000, according to the Toronto Star (www.thestar.com/news/canada /article/1093698 - the-canadian-medical -association-journal-calls-for-scrapping -hospital-parking-fees).

Similarly, regional health authorities other than Fraser Health reported revenues in British Columbia. Northern Health earned $\$ 306430$ in fiscal 2010/11, while Interior Health earned $\$ 3.5$ million and the Vancouver Island Health Authority \$6 million, according to the Vancouver Sun (www.vancouver sun.com/technology/topics/city/amman /Hospital+parking+fees+slammed/5780 172/story.html). - Kayla Redstone, Ottawa, Ont.

CMAJ 2012. DOI:10.1503/cmaj.109-4095 